\title{
A principal artéria fluvial da Amazônia brasileira como nodal do transporte rodoviário de carga
}

\section{The main waterway of the Brazilian Amazon as a nodal the road freight}

Daniel Monteiro Huertas - Doutor em Geografia Humana (Universidade de São Paulo, 2013). Mestrado em Geografia (Geografia Humana). Graduação em Geografia. Graduação em Jornalismo. Exerce o cargo de professor adjunto do Eixo Comum na Universidade Federal de São Paulo (Unifesp), campus Osasco. E-mail: dmh@usp.br/ dmhuertas@unifesp.br

\section{Resumo}

Em análise estruturada a partir da teoria do espaço geográfico, este artigo pretende demonstrar as peculiaridades e dinâmicas territorias que corroboram a inserção do eixo nodal Manaus-Belém como uma das centralidades da rede geográfica do transporte rodoviário de carga, cuja configuração territorial é composta por linhas e nodais que em seu conjunto expressam a organização e estruturação desta atividade na formação socioespacial brasileira e evidenciam um processo de seletividade espacial que privilegiou certos pontos e áreas em detrimento de outros, demarcado pela concentração e atuação de seus agentes.

\section{Palavras-chave}

Amazônia. Transporte rodoviário de carga. Circulação. Nodal e Seletividade Espacial.

\begin{abstract}
In structured analysis from the theory of geographical space, this article aims to demonstrate the peculiarities and territorial dynamics that confirmed the insertion of the nodal axis ManausBelém like one of centralities of road freight transport geographical network, whose territorial configuration consists of nodals and lines which together express the organization and structuring of this activity in the Brazilian social and spatial formation and show a selective spatial process that privileged certain points and areas in detriment of others, marked by concentration and action of its agents.
\end{abstract}




\section{INTRODUÇÃO}

O aprofundamento e a capilaridade da globalização pelo território nacional a partir de meados dos anos 1990 impuseram mudanças profundas no cenário do comércio exterior, das forças produtivas e do padrão de consumo, elementos que, em conjunto, também impactaram o transporte rodoviário de carga, cujas variáveis são capazes de revelar o uso do território no período atual. Nessa perspectiva, a logística, como versão atual da circulação corporativa caracterizada por um conjunto de competências operacionais, materiais e normativas (CASTILLO, 2011), surge de forma arrebatadora e acarreta mudanças estruturais e conjunturais em toda a instância produtiva e no seu enlace com a circulação.

A promulgação da lei no 11.442 , de 5 de janeiro de 2007, instituiu um novo quadro normativo e enquadrou o transporte rodoviário de carga (TRC) como aquele "realizado em vias públicas, no território nacional, por conta de terceiros e mediante remuneração", cuja atividade econômica "é de natureza comercial, exercida por pessoa física ou jurídica em regime de livre concorrência", segundo os artigos $1^{\circ}$ e $2^{\circ}$ da lei supracitada.

A norma, portanto, distingue o transporte rodoviário de carga da figura do carga própria (agente que não realiza o transporte com natureza comercial) e também procura discriminar e disciplinar os seus agentes (empresas de transporte rodoviário de carga/ETC e transportadores autônomos de carga/ TAC, agregados e independentes) e atividades correlatas mediante coordenação e fiscalização da Agência Nacional de Transportes Terrestres (ANTT). Tratase de um universo de 128.700 empresas transportadoras, 689.953 motoristas autônomos e 1.911.172 veículos espalhados por todos os cantos do país, segundo dados da ANT'T (15.mai.2013).

Em análise estruturada a partir da teoria do espaço geográfico, o uso do território pode ser evidenciado por um processo de seletividade espacial que privilegiou certos pontos e áreas em detrimento de outros. Como o transporte também pode ser considerado um dos fatores locacionais por conta das possibilidades que oferece para a redução de custos (THOMSON, 1976), os agentes dos circuitos espaciais de produção (SANTOS, 1988) buscam atuar em sintonia com os agentes do TRC.

As solidariedades organizacionais geradas estimulam e facilitam a localização dos agentes em pontos privilegiados do território, geralmente nodais situados em tramos estratégicos da rede rodoviária e da rede urbana. Afinal, como já nos disse Milton Santos (2004) em sua análise do imperativo da fluidez, não basta produzir; é indispensável pôr a produção em movimento.

Novos Cadernos NAEA • v. 17 n. $2 \cdot$ p. 95-122 • dez. 2014 
Levando-se em consideração que o TRC cria uma topologia própria, cuja configuração territorial é composta por linhas e nodais que em seu conjunto modelam uma rede geográfica capaz de expressar a sua organização e estruturação na formação socioespacial brasileira (HUERTAS, 2013), este artigo pretende demonstrar as peculiaridades e dinâmicas territorias que corroboram a inserção do eixo nodal Manaus-Belém como uma das centralidades da rede em questão.

Trata-se de um nodal secundário polifuncional, diretamente atrelado à logística de atividades industriais (como será visto mais adiante), que em seu conjunto registra 28 matrizes de empresas transportadoras e 158 filiais espalhadas por nove cidades, segundo a pesquisa realizada. O eixo central deste nodal, entretanto, não é rodoviário, fato que por si só evidencia uma das dinâmicas territoriais da formação socioespacial brasileira, a intermolidade rodofluvial praticada na Amazônia.

\section{NODAIS COMO MÁXIMA EXPRESSÃO DA SELETIVIDADE ESPACIAL}

O ponto inicial analítico proposto, em termos de circulação, é a configuração de uma rede geográfica do transporte rodoviário de carga reveladora do uso do território. Corrêa (1997, p. 306) demonstra como as redes geográficas são construções sociais "historicamente contextualizadas, constituindo-se em parte integrante do longo e cada vez mais complexo processo de organização espacial”, e locus da efetivação das interações espacias "a partir dos atributos das localizações e das possibilidades reais de se articularem entre si”.

Organizamos o estudo da rede geográfica em questão para o território brasileiro levando em consideração funcionalidades, hierarquias e polarizações, atributos que em seu conjunto mais amplo denotam tanto a dissociação quanto a conectividade geográfica dos lugares e a seletividade espacial. Acreditamos, assim, que este caminho metodológico proporcione uma leitura bastante interessante no que diz respeito ao uso do território, evidenciando com mais força a hierarquia dos lugares gerada pela circulação diferenciada do excedente (ARROYO, 2005).

Os nodais ajudam a explicar a rede geográfica e são tidos, portanto, como a expressão máxima da seletividade espacial do transporte rodoviário de carga pela densidade de fixos e pela frequência, qualidade e intensidade dos fluxos. Do ponto de vista operacional, apenas nos nodais registra-se a possibilidade de implementar uma distribuição territorial completa das mercadorias em fluxos T1 (escala nacional-T1/A, macrorregional-T1/B e mesorregional-T1/C) e T2 
(escala microrregional-T2/D, intraurbana metropolitana-T2/E e intraurbana intermediária-T2/F), cujos movimentos demarcam a escala de atuação de empresas transportadoras e motoristas autônomos (HUERTAS, 2013).

Além disso, são os principais pontos de origem e destino de todo o movimento de carga lotação (ou carga fechada, com carregamento num único ponto e entrega num único ponto) empreendido no país, embora não haja estatísticas que possam comprovar este fenômeno.

Logo de imediato é importante salientar algumas considerações gerais a respeito dos nodais. Em todos os casos ocorre uma espécie de "nexo territorial", consubstanciado pela conjugação entre a capacidade dos agentes instalados em condicionar arranjos territoriais em todas as escalas (fluxos T1 e T2), a formação do valor do frete e as amplas condições de fluidez territorial, o que significa situação locacional em trechos privilegiados da rede rodoviária nacional e acesso facilitado a portos, ferrovias, hidrovias e aeroportos. Corresponde, portanto, às interações espaciais que reforçam a interconectividade entre os agentes do transporte rodoviário de carga e destes com os agentes dos circuitos espaciais de produção.

Esta condição única no território nacional, portadora de verticalidades que criam e recriam solidariedades organizacionais, revela a estrutura e organização socioeconômica e política superior dos nodais em relação ao TRC. "as metrópoles econômicas nacionais usufruem de posição estratégica na moderna rede de transporte. Isso lhes assegura relações mais fáceis com o resto do território, aumentando assim sua capacidade de competição" (SANTOS, 2008, p. 309).

As características acima denotam a localização dos fixos mais estratégicos em termos de expedição, transferência e consolidação de carga e capacidade de armazenagem, além da presença de pessoal mais qualificado para o desenvolvimento das tarefas administrativas e operacionais que envolvem o TRC. Segundo estudo do Geipot citado por Silva Junior (2004), 1/3 do total da frota de caminhões do país opera em percursos rodoviários (fluxos T1 e T2/D), viagens de média e longa distância com custos de transferência representativos por causa dos fixos. Soma-se a isso o fato de que nas operações de coleta e entrega (fluxos T2/E e T2/F), cujo volume também está bastante concentrado nos nodais, os custos fixos dos veículos pefazem mais de $60 \%$ do total dos custos operacionais, segundo Giúdice (2012).

Entende-se assim que os nodais concentram boa parte dos custos totais do TRC, elemento fundamental para o planejamento estratégico do circuito superior. No plano político, concentram grande parte das instituições 
responsáveis pela representação de suas categorias, com capacidade de debater e direcionar os assuntos normativos correlatos à atividade, com forte influência na regulamentação do setor. "Em regra geral, os atores que possuem os nós detêm o controle dos dispositivos: é nos polos que se efetua o tratamento estatístico dos objetos, garantia da qualidade da prestação global, que se organiza a cadeia de entrega com suas subcontratações hierárquicas" (SAVY, 1993, p. 216; tradução livre).

De modo geral, observa-se que todas as características supracitadas são típicas de cidades com maiores níveis de especialização e diversificação econômica, em hierarquias superiores na rede urbana brasileira, cuja concentração de variáveis diretamente relacionadas ao TRC proporciona uma sinergia territorial entre os agentes e acaba reforçando o poder de polarização e centralidade das aglomerações urbanas onde se localizam - geralmente no entorno de grandes cidades, nós de circulação e pontos de convergência das vias de comunicação com interpentração de circulação geral e local (CLOZIER, 1963).

No processo de urbanização, há [...] uma tendência crescente à diferenciação e à especialização, acompanhada de uma maior divisão interurbana do trabalho, e atrelada diretamente às possibilidades de articulação que a dinâmica da circulação promove (ARROYO, 2006, p. 76).

De certa forma o nodal está vinculado a uma economia complexa, "caracterizada, e viabilizada, por uma complexa divisão territorial do trabalho", e associado à rede urbana, "cujos centros estão fortemente integrados entre si" (CÔRREA, 2006, p.306). Mas os nodais também revelam situações intermediárias, que ajudam a compreender com mais profundidade a correlação de forças entre os agentes do transporte rodoviário de carga e os níveis inferiores da rede urbana brasileira.

Esses sistemas de tessituras, de nós e de redes organizadas hierarquicamente permitem assegurar o controle sobre aquilo que ser distribuído, alocado e/ou possuído. Permitem ainda impor e manter uma ou várias ordens. Enfim, permitem realizar a integração e a coesão dos territórios. Esses sistemas constituem o invólucro no qual se originam as relações de poder (RAFFESTIN, 1993, p. 151).

Além disso, se a circulação diferenciada do excedente cria uma hierarquia entre os lugares (ARROYO, 2005), os nodais podem ser analisados, também, pelas grandes possibilidades que oferecem para reter boa parte deste excedente, porque "sem a circulação de bens não há circulação do excedente" (SANTOS, 2003, p. 144). 
São nos nodais que se materializam no território as maiores possibilidades daquelas metamorfoses M-D e D-M explicadas por Marx, fenômeno que intensifica o que ele chamou de "processo adicional da produção da indústria de transportes", visível na densidade do trinômio proposto. Além disso, são nos nodais que a aplicação da lei geral da produção de mercadorias, que também "se aplica à indústria de transportes como a qualquer outra” (MARX, 2011, p.167), adquire a sua condição plena, pois a concentração de agentes da circulação nesses nexos territoriais favorece a diminuição dos custos de transporte.

Ademais, valendo-se ainda da teoria marxista, são nos nodais que residem as maiores possibilidades de balanceamento entre o tempo de compra e de venda - cuja soma define o tempo de circulação do capital, uma das frações do ciclo de circulação do capital como um todo -, pois “o afastamento do mercado prolonga o tempo em que o capital fica prisioneiro da forma de capital-mercadoria, retarda diretamente o retorno do dinheiro, por conseguinte a transformação do capitaldinheiro em capital-produtivo" (MARX, 2011, p. 290).

O autor explica que a repartição do retorno do dinheiro "por maior número de períodos sucessivos encurta o tempo global de circulação e, por conseguinte, a rotação" (MARX, 2011, p. 287), condição possível, para o caso específico da formação socioespacial brasileira, pelo entrelaçamento territorial proporcionado pelos nodais, que amarram os principais mercados produtores e consumidores de um país com dimensões continentais e desequilíbrios regionais.

Nos nodais observa-se um melhor desenvolvimento dos meios de transporte, fato que "aumenta a velocidade do movimento no espaço e assim reduz-se no tempo a distância geográfica” (MARX, 2011, p. 286). Esta redução absoluta do tempo de viagem das mercadorias, embora permaneça a diferença relativa, só é possível pela maior frequência com que funcionam os agentes da circulação nos nodais, além da amplitude de suas escalas de atuação no território nacional.

$\mathrm{Na}$ divisão territorial do trabalho do período atual, os nodais do transporte rodoviário de carga, locus de alta produtividade espacial ou subsistemas logísticos que facilitam a fluidez e hierarquizam o território pelos seus requisitos técnicoorganizacionais (SANTOS, 2004), proporcionam um movimento convergente de articulação do todo nacional, embora o espaço se torne "mais articulado às relações funcionais, e mais desarticulado quanto ao comando local das ações que nele se exercem" (SANTOS, 2005, p. 49). A análise geográfica, portanto, parte do princípio de que o espaço também se impõe por meio das condições que oferece para a circulação. 


\section{ATRIBUTOS GEOGRÁFICOS DOS NODAIS QUE REFORÇAM CENTRALIDADES}

Como visto anteriormente, o nodal denota a capacidade de produzir, coletar, armazenar e distribuir das áreas sob sua influência e se torna uma arena territorial privilegiada aos agentes por causa da cadeia de subcontratações, que aí encontra as maiores probabilidades de realização pelo encontro entre oferta e demanda por serviço de transporte. No embate entre arena e área, proposto por Milton Santos (2005), os nodais são arenas que proporcionam o alargamento de atuação territorial dos agentes dos circuitos inferior e superior, ou seja, de suas áreas de operação - que podem ser rotas programadas ou de acordo com a conveniência do cliente.

Como escolher, então, as variáveis, ou melhor, os atributos geográficos constituintes dos nodais do TRC? Ao longo da pesquisa, fruto da observação empírica de nosso objeto de estudo, foi concebido um agrupamento tipológico sob o prisma da correlação do trinômio máquina (veículo) $\leftrightarrow$ agentes da circulação $\leftrightarrow$ fixos (rodovias e suportes). Os elementos escolhidos e discriminados abaixo, com elevado grau de concentração nos nodais, tem como objetivo comprovar territorialmente a densidade e escala de objetos ligados direta ou indiretamente ao TRC, o que de certa forma ajuda a corroborar a hierarquia dos lugares no que diz respeito à circulação:

(1) Veículos: revendas de todas as marcas de caminhão comercializadas no Brasil (Agrale, Ford, Hyundai, International, Iveco, MAN, Mercedes-Benz, Scania, Volvo e Sinotruk); rede de distribuidores dos cinco mais expressivos fabricantes de implementos rodoviários (Randon, Librelato, Facchini, Noma e Guerra) e oficinas Bosch Diesel Center, tidas como especializadas em serviços mecânicos e eletrônicos com soluções de reparo dos sistemas diesel (Common Rail e outros) em equipamentos de última geração.

Também é importante destacar que ao longo dos nodais, mais especificamente nas principais vias e trevos de acesso às cidades que os compõem, registra-se uma miríade de oficinas que prestam inúmeros serviços de manutenção e reparo de caminhões e implementos rodoviários, borracharias e revendas de veículos usados. São estabelecimentos de todos os portes - precários e modernos; pequenos, médios e grandes -, mas constantemente presentes na paisagem. Alguns funcionam 24 horas, sempre aptos a prestar assistência ao caminhoneiro.

Dentre os serviços mais ofertados estão chapeação (funilaria), pintura, lavagem, autoelétrico, recapagem de pneu, retífica e usinagem de motores, substituição de bomba injetora de óleo diesel, troca de lona de freio e reparo de 
diferencial e caixa de câmbio. Os postos de combustível, além do abastecimento, funcionam como ponto de apoio e oferecem pequenos serviços emergenciais de mecânica, lavagem, calibragem de pneus, sanitários, restaurante e estacionamento para pernoite. Alguns ainda possuem serviços como barbearia, salão de jogos, sala de TV, comércio de artigos para caminhão (adornos, enfeites, lâmpadas, para-choques, adesivos etc) e agenciamento de carga.

(2) Agentes: Empresas transportadoras de carga (ETC) e transportadores autônomos de carga (TAC) cadastrados no Registro Nacional de Transportadores Rodoviários de Carga (RNTRC) da ANT'T; motoristas com vínculo empregatício segundo a Relação Anual de Relações Sociais do Ministério do Trabalho e Emprego (Rais/MTE); unidades do Sistema Sest/Senat, mantido pela contribuição sindical de todos os agentes e gerenciado pela Confederação Nacional dos Transportes (CNT), e organização sindical do empresariado e de autônomos.

(3) Fixos logísticos: cada tipo de fixo surge com características próprias (técnicas e organizacionais) que corresponde a uma tipologia de fluxos (SANTOS, 1988). Desse modo o funcionamento do território não pode ser compreendido sem a alocação dos fixos que captam o movimento de boa parte dos fluxos rodoviários que perpassam o território nacional, seja para o mercado interno ou externo. Além disso, são grandes indicadores das forças de dispersão e concentração geradas pelo binômio informação-consumo (SANTOS, 2008), ponto central para a compreensão dos circuitos espacias e círculos de cooperação do TRC.

Em sua proposição de uma tipologia de nós geográficos, Braga (2013, p. 45) coloca como objetivo "discriminar e classificar os sistemas técnicos que envolvem o movimento de mercadorias, sem esquecer as relações políticas, econômicas e sociais que articulam e hierarquizam estes pontos, planejados para serem estrategicamente localizados no território”. Para o autor, os nós geográficos podem ser classificados "de acordo com sua função e complexidade, decorrentes de distintas combinações entre objetos técnicos e normas que incorporam" e estão subdivididos em nós de comunicação e de circulação. Estes, por sua vez, incorporam nós de transporte de passageiros, de transporte de cargas simples e logísticos.

Levando-se em consideração os dois últimos, que nos interessam mais de perto, observamos que armazéns simples, centrais (ou centros) de distribuição, plataformas e condomínios logísticos, terminais intermodais (aeroportuários, aquaviários e ferroviários) e centros logísticos e industriais aduaneiros (Clias) estão entre os fixos adotados pelo autor para corroborar o seu ponto de vista. Em nossa análise, focada no TRC, acrescentaremos os pontos de combustível com agenciamento de carga, os recintos alfandegados pela Receita Federal (portos 
secos e pontos de fronteira), as unidades superiores de triagem dos Correios e os entrepostos da Zona Franca de Manaus (EZFM).

(4) Rede rodoviária: em conjunto com os nodais, as linhas rodoviárias de circulação revelam a rede geográfica do TRC. Como aponta Brandão (2009, p. 78-9), "tornar os espaços conexos não é uma tarefa que ocorre com naturalidade", e a ação das forças de integração "geralmente constitui um longo, contraditório, heterogêneo e conflituoso processo em que os espaços regionais circunscritos e capsulares vão sendo enredados a partir daquele(s) espaço(s) em que prevalecem formas superiores de acumulação e reprodução econômica".

É fato que a expansão rodoviária no país é iniciada nos anos 1930 com Getúlio Vargas e incrementada sucessivamente por Juscelino Kubitschek e pela ditadura militar ao longo da segunda metade do século XX. Em outras palavras, o enraizamento das linhas rodoviárias só pode ser compreendido mediante análise do processo histórico da formação socioespacial brasileira, que deve mostrar porque uma via foi aberta; e mais, porque foi aberta para ligar os pontos A e B, e não A e C. Geralmente, há um imbricamento de motivações geoeconômicas e geopolíticas; muitas vezes, uma prevalece sobre a outra.

Mas como pensar as linhas de circulação para a proposta deste trabalho e para o período atual? Primeiramente concordamos com a assertiva de Santos (2008, p. 313) sobre a rede de transportes nos países subdesenvolvidos, "nem homogênea nem contínua, mas dendrítica", cujas principais rodovias "ligam os grandes centros de produção aos principais centros de consumo". Optamos por um esquema simples, composto por três conjuntos rodoviários:

- Eixos centrais (estruturantes): são as ligações de alta densidade de tráfego e de grande importância geoestratégica, uma malha de linhas de circulação que conecta os nodais superiores do TRC majoritariamente por rodovias federais (BRs). Em termos econômicos confundem-se com as linhas de desejo que servem as principais economias de escala do país.

- Eixos complementares: são ligações de média densidade de tráfego e de caráter mais intrarregional e/ou intraestadual do que inter-regional e/ou interestadual. Compõem as rodovias que atendem os eixos centrais tanto no seio dos nodais quanto na ligação entre linhas de nível superior. Neste caso, aparece um conjunto bastante significante de vias estaduais, sobretudo na Região Concentrada.

- Eixos em configuração na Amazônia: incluída no Programa de Aceleração do Crescimento (PAC), a pavimentação em andamento dos trechos Guarantã do Norte/MT-Santarém/PA da Cuiabá-Santarém (BR-163), Altamira-Marabá da Transamazônica (BR-230/PA) e Ribeirão Cascalheira/MT-divisa MT/PA da 
BR-158 a curto e médio prazos modificará a configuração territorial de extensas áreas entre o sul do Pará e o médio-norte do Mato Grosso, com iminentes impactos socioambientais.

\section{RECORTES ESPACIAIS E TOPOLOGIA DOS NODAIS}

Acreditamos que a busca por uma rede geográfica promovida e desenhada pelo TRC como resultado da divisão territorial do trabalho encontre sentido exatamente nesta questão, a definição de espaços de fluxos reguladores - os nodais em suas manifestações topológicas - interligados por linhas de circulação que abarcam boa parte do território nacional. Admitimos, entretanto, que esta escolha pode incorrer em erros comuns a qualquer tipo de recorte espacial estabelecido a partir de quaisquer variáveis. Não se trata de uma camisa-deforça, mas de uma sugestão para um melhor entendimento do papel do TRC na organização e estruturação da formação socioespacial brasileira.

Os nodais não deixam de ser aglomerações e a compreensão da divisão territorial do trabalho inclui, necessariamente, a análise funcional e hierárquica do TRC - evidenciando, assim, o uso do território. Santos (2004, p. 284; grifo nosso) nos explica que, nas atuais condições, "os arranjos espaciais não se dão apenas através de figuras formadas de pontos contínuos e contíguos". E continua: "Hoje, ao lado dessas manchas, ou por sobre essas manchas, há, também, constelações de pontos descontínuos, mas interligados, que definem um espaço de fluxos reguladores."

O recorte espacial dos nodais, como proposta metodológica, considera a relação entre quantidade e contiguidade de matrizes e seus fixos correlatos (filiais, centros de operação, pontos de apoio, centros de distribuição, agências, centros de envio e franquias) de uma relação de 800 empresas transportadoras levantadas em pesquisa de elaboração própria como o indicador que esclarece os arranjos territoriais do TRC ao longo da formação socioespacial brasileira, relacionando-o com a rede rodoviária nacional e a rede urbana (HUERTAS, 2013). A pesquisa apontou 7.401 fixos em 1.087 cidades de todas as Unidades da Federação, sendo que, respectivamente, 6.936 (93,71\%) e 695 (63,93\%) estão situados nos nodais, classificados em quatro níveis:

(i) Primário: "polígono paulista", força polarizadora única no território nacional que acolhe 304 matrizes (38\% do total), com 1.618 fixos (21,8\%) alocados em 144 cidades (13,2\%), e responsável pela determinação das rotas, prazos de tempo de trânsito de carga e valor do frete de boa parte do país;

Novos Cadernos NAEA • v. 17 n. 2 • p. 95-122 • dez. 2014 
(ii) Secundários polifuncionais: aqueles em que os circuitos espaciais de produção industrial são o suporte das atividades geradoras de carga, tornando o seu tecido econômico mais diversificado e complexo;

(iii) Secundários monofuncionais: aqueles cuja tipologia pode estar relacionada à especialização produtiva (circuitos espaciais de produção petrolífera e agropecuária), à situação geográfica (acesso fronteiriço ao Mercosul) ou à logística do comércio atacadista e distribuidor e da produção salineira;

(iv) Terciários (relês regionais): centros responsáveis por fluxos T2/D (rotas microrregionais) e $\mathrm{T} 2 / \mathrm{F}$ (cidades intermediárias).

A configuração de um nodal em cidades que dispõem de pelo menos três fixos e/ou de uma matriz é uma condição restrita ao nodal terciário, o mais baixo da classificação proposta. Os dois níveis superiores, ou nodais primários e secundários, somente ocorrem em cidades com seis ou mais fixos e pelo menos uma matriz, sendo que a sua composição completa, no caso de eixos e polígonos, deve incluir também todas as cidades adjacentes aos seus eixos rodoviários estruturantes que contam com pelo menos um fixo.

De certa forma, esta proposta metodológica constrói-se a partir do circuito superior do transporte rodoviário de carga (grandes e médias transportadoras), embora os circuitos superior marginal e inferior (pequenas transportadoras e motoristas autônomos) estejam diretamente atrelados e subordinados, espacialmente falando, aos desígnios técnico-operacionais e informacionais dos agentes hegemônicos.

A pesquisa desenvolvida ainda indica que as empresas de transporte rodoviário de carga pensam o Brasil no sentido longitudinal (norte-sul), até uma faixa de cerca de $200 \mathrm{~km}$ do litoral no Nordeste e de $600 \mathrm{~km}$ na Região Concentrada - obviamente onde se concentram os seus principais centros produtores e consumidores. Fora dessa zona, apenas alguns nodais e relês aparecem como centralidades associadas ao TRC no Brasil contemporâneo, fato que de certa forma demonstra a leitura territorial de "estilo christalliana" exercida pelo mercado.

Isso também significa que, de forma geral, o atendimento ao extenso interior do país é feito de modo mais otimizado e lento, pois o crescimento das distâncias é proporcional à diminuição dos mercados (ou seja, menos carga para transportar), situação que requer do transportador ajustes, adaptações e parcerias. A pesquisa também demonstra que a distribuição espacial de nodais ao longo do território nacional pode ser um dos indicadores das crônicas e históricas desigualdades regionais, principal característica da formação socioespacial brasileira. 


\section{EIXO MANAUS-BELÉM: 1.650 QUILÔMETROS PELA ARTÉRIA FLUVIAL DA AMAZÔNIA}

Uma das principais particularidades do TRC brasileiro é uma contradição: um de seus mais importantes eixos de circulação, o eixo Manaus-Belém (Diagrama 1), é hidroviário, fato igualmente relevante para a compreensão da formação socioespacial brasileira. A viagem de carretas em balsas foi uma das saídas encontradas pelo setor privado, em consonância com órgãos públicos, para amenizar as desvantagens logísticas do suprimento e escoamento de Manaus, maior cidade de toda a Bacia Amazônica e berço de um polo industrial desenvolvido a partir da criação da Zona Franca de Manaus (ZFM), em 1957.

Exatos 10 anos após a sua criação, a ZFM foi alavancada com a criação da Superintendência da Zona Franca de Manaus (Suframa), que previa a instalação de um distrito industrial na cidade para estimular e favorecer a iniciativa privada e a substituição de importações. Eram os tempos do "milagre econômico brasileiro", que na Amazônia Legal incorporou o mantra da ditadura militar do binômio integração e segurança nacional com um arcabouço normativo consubstanciado na "Operação Amazônia” (HUERTAS, 2009).

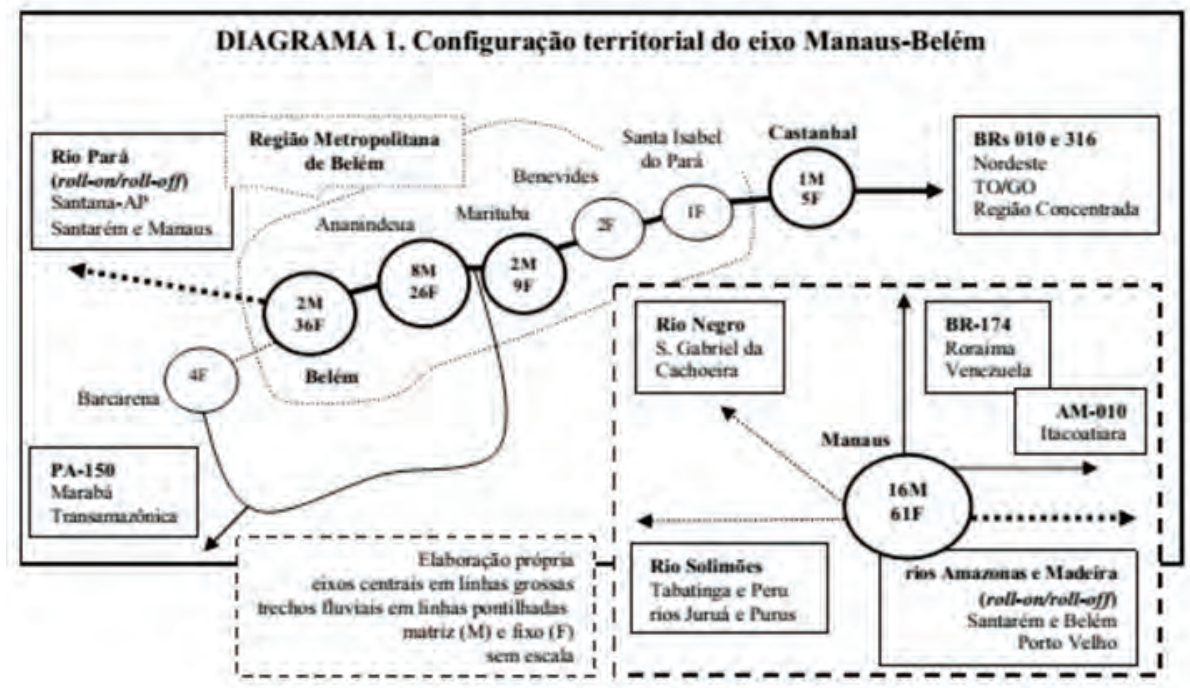

Alcançar o coração da floresta era preciso para os objetivos da época, já que a Amazônia tornara-se um novo alvo do capital. Como a ligação rodoviária de $901 \mathrm{~km}$ entre Porto Velho e Manaus tornara-se impraticável por causa de seu alto custo de manutenção - no final dos anos 1980 a BR-319 ficou intransitável -, e a cabotagem estava em declínio, a saída encontrada foi uma adaptação 
tecnológica que pudesse otimizar a navegação no estirão fluvial Belém-Manaus, favorecendo a ligação com os principais centros econômicos do país pela rodovia Belém-Brasília.

O sistema roll-on/roll-off consiste na adequação de um equipamento flutuante para o transporte de veículo, "o próprio objeto transportado e por seus próprios meios, que se movimenta para dentro e para fora da embarcação, sendo essa a origem de sua denominação" (NAZARÉ, 1983, p. 4), grifo no original). Dessa forma, a balsa transporta apenas o semirreboque do veículo, que acaba por constituir a unidade de carga, uma espécie de "contêiner sobre rodas" desconectado de sua unidade tracionadora (o cavalo mecânico).

Desenvolvido nos Estados Unidos na década de 1950, na Amazônia o sistema sofreu duas adaptações técnicas - a substituição do sistema de reboque pelo de empurra e do uso do convés em vez do porão - que tornariam a configuração hidrodinâmica da embarcação mais adequada e eficiente. Rebatizado de "ro-ro caboclo", sua incorporação e regulamentação à navegação interior foi efetuada pela Superintendência Nacional da Marinha Mercante (Sunaman) com as resoluções 5.539/77 e 6.151/79. Como resultado, nos rios amazônicos os navios foram preteridos pelos comboios de balsas de diferentes capacidades (até quatro balsas, cuja configuração pode conduzir 12, 16, 25, 48 ou 64 carretas), deslocados rio acima ou rio abaixo por empurradores de potências variadas.

O Polo Industrial de Manaus (PIM), um modelo baseado na atividade industrial de alguns segmentos com incentivos fiscais ${ }^{1}$ responsável pela arrecadação de mais de 50\% dos tributos federais gerados na Região Norte, atualmente vive um momento de euforia pelas altas taxas de crescimento, com foco na eficiência exportadora e no incremento da eficiência produtiva e da capacidade de inovação das empresas. Segundo dados oficiais da Suframa, o faturamento do PIM em 2012 foi de $\mathrm{R} \$ 73,4$ bilhões (mercado interno e externo), produzido por cerca de 600 empresas instaladas que geram 120 mil empregos diretos, com destaque para os segmentos de duas rodas (motocicletas, ciclomotores, motonetas, bicicletas e similares), televisores de LCD/LED, celulares e microcomputadores.

A expansão da produção, entretanto, tem na logística de e para Manaus um elemento complicador. É preciso salientar que o advento do "ro-ro caboclo" engendrou um igual crescimento do TRC na capital amazonense, que passou a

Em 2003, a Emenda Constitucional n 19 prorrogou o modelo ZFM até 2023. Seus atrativos fiscais são a redução de até $88 \%$ do Imposto de Importação (II); isenção total do Imposto sobre Produtos Industrializados (PIM); redução de 75\% do Imposto de Renda (IR); isenção da contribuição para o PIS/Pasep e Cofins nas operações internas na ZFM e restituição de $55 \%$ a 100\% do ICMS, além de isenção do IPTU e taxas de serviços de coleta de lixo, limpeza pública, conservação de vias e logradouros públicos e taxas de licença para empresas que geram um mínimo de 500 empregos. 
contar com filiais de grandes ETCs de outras partes do país, além de configurar uma divisão do trabalho peculiar. Como os fluxos interregionais dependem da intermodalidade com o transporte hidroviário (5 dias entre Manaus-Belém e 7 dias no retorno), os agentes do TRC preocupam-se com a coleta nas fábricas do PIM, o embarque de sua carreta nas balsas e o desembarque em Belém.

O Sindicato das Empresas de Agenciamento, Logística e Transportes Aéreos e Rodoviários de Cargas do Estado do Amazonas (Setcam) estima que cerca de 15 mil carretas entram e saem de Manaus por mês, totalizando 500 veículos e 9 mil toneladas por dia. Os dois principais fluxos interregionais, calcula a entidade, são Manaus $\leftrightarrow$ São Paulo e Manaus $\rightarrow$ Nordeste $(20 \%)$, levando-se em consideração o transbordo intermodal na capital paraense. O crescimento do roubo de cargas nas balsas (tido pelos agentes como pirataria) fez com que em 2011 o gasto com segurança estivesse entre os três maiores investimentos das ETCs filiadas ao Setcam.

Em Belém, a outra ponta da perna fluvial, o embarque e/ou desembarque depende do nível da maré. Nos fluxos para São Paulo, os cavalos mecânicos operam em regime de just-in-time para acoplar os semirreboques e seguir para as filiais das ETCs para o reprocesso da carga, um procedimento que dura em média 12 horas. A perna rodoviária de $3.000 \mathrm{~km}$ pela Belém-Brasília é realizada de 3 a 4 dias. Os principais pontos de apoio até Anápolis são os postos Imprecol, em Porto Franco (MA); Tabocão, em Guaraí (TO); Carreteiro, em Barrolândia (TO); Décio e Marajó, em Gurupi (TO) e Matinha, em Campinorte (GO). Tanto Belém quanto Manaus possuem portos secos instalados.

Açailândia e Imperatriz, no trecho da Belém-Brasília que corta o Maranhão, também são importantes centros regionais geradores e distribuidores de carga. A rota mais usual segue em linha reta até Anápolis, para em seguida pegar as BRs 060 e 153 sentido Goiânia, Itumbiara (GO), Frutal (MG) e Barretos (SP). Em São Paulo, já na SP-326, os veículos pegam a SP-253 em Jaboticabal para sair na Anhanguera na altura de Luís Antônio, escapando assim dos pesados pedágios da Washington Luís (SP-310) e do trecho da Anhanguera entre Igarapava e Ribeirão Preto. Este artifício é conhecido como "funil de Manaus".

Por causa dos incentivos fiscais da Suframa, todos os fretes de saída de Manaus são $\mathrm{CIF}^{2}$ e todo o movimento fica restrito a um raio de $20 \mathrm{~km}$, com saída e entrada das carretas em três portos - Chibatão (da empresa J. F. Oliveira Navegação, conhecida como Passarão), Bertolini e Silnave, em pequena escala.

\footnotetext{
2 No Brasil, o mercado do TRC também adotou as cláusulas FOB (Free on Board) e CIF (Cost, Insurance and Freight) utilizadas no comércio internacional, que definem formas completamente distintas de aquisição do serviço de transporte. Na primeira, o frete é pago pelo destinatário, ou seja, pelo comprador da mercadoria; na outra, é pago pelo remetente, ou seja, pelo embarcador.
}

Novos Cadernos NAEA • v. 17 n. $2 \cdot$ p. 95-122 • dez. 2014 
Esta circulação (fluxo T2/E) entre o PIM e os portos da capital é o principal de todo o Estado, de acordo com a Setcam. A escolha cabe à empresa transportadora, mas como a Bertolini é uma empresa de transportes que dispõe dos dois modais 95\% de seu movimento fluvial é Manaus-Belém, e o restante dividido entre Porto Velho, Santana (AP) e Itaituba (PA), segundo Trevisan (2012) -, reserva apenas $20 \%$ de sua capacidade na perna fluvial para outras ETCs, com fretes de $15 \%$ a 20\% mais altos em três saídas semanais, conforme explicou Sérgio Quevedo (informação verbal) ${ }^{3}$, supervisor operacional da filial da TNT em Manaus.

Por sua vez, o Chibatão oferece saídas diárias de um conjunto de um empurrador para três balsas (120 carretas), enquanto o equipamento da Bertolini (Fotografia 1) opera apenas duas balsas com 25 carretas no total.

Fotografia 1 - Balsa da Transportes Bertolini

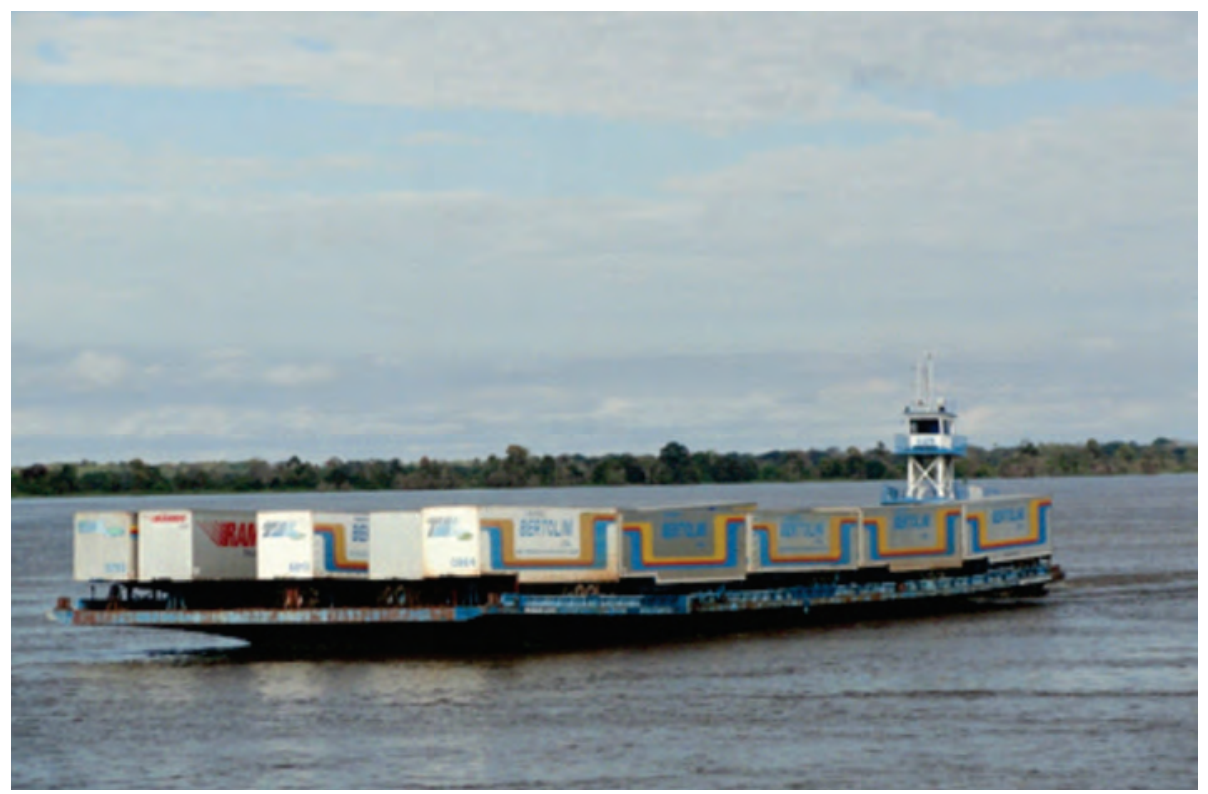

Autor: Daniel M. Huertas (11.jul.2012).

De meados dos anos 2000 em diante o TRC vem sofrendo com a retomada da cabotagem, que desde então tem crescido gradativamente e tomado espaço da intermodalidade rodofluvial. Para Quevedo, "os armadores não tinham compromisso com a rota de Manaus, operada apenas pela Docenave e Aliança”. O marco, para ele, foi a entrada da Mercosul Line em 2002 na rota para a capital amazonense, empresa posteriormente comprada pela dinamarquesa Maersk Line. "Era uma rota desacreditada e a Mercosul passou a criar raízes

Entrevista concedida em Manaus em 09.julho.2012. 
mostrando os benefícios de seus serviços, como maior segurança, custo mais baixo e avaria zero." As desvantagens para a intermodalidade rodofluvial são o tempo de trânsito mais longo e a sazonalidade do período de chuvas, que exige a diminuição da frequência e produtividade dos navios na vazante, de junho a novembro.

Em 10 anos, houve a saída da Docenave, a reestruturação da Aliança para brigar com a Mercosul (hoje Log-In Logística Intermodal, em associação com os navios da Mercosul) e a entrada da Maestra, do Grupo Triunfo, como atesta Fonseca (2013). O resultado foi um aumento real da cabotagem desde 2008, que chegou a 35\% em 2011, segundo Quevedo. "Houve uma migração em massa para a cabotagem, e até Honda e Nokia estão testando a modalidade."

De acordo com Fábio Carvalho, gerente de transportes da Supporte Logística Integrada, apenas a Log-In carregou em 2011 cerca de 2,5 mil contêineres, o equivalente a 1,9 mil carretas, gerando ociosidade de veículos em Manaus. A situação agrava-se no período de férias coletivas (janeiro e julho), ampliando a sobra de carretas - apenas Honda e Yamaha deixam de operar 130 carretas por dia (informação verbal) ${ }^{4}$.

Na cabotagem, a presença de TACs é rarefeita, já que poucos dispõem de carreta porta-contêiner para coletar o contêiner na fábrica, onde é estufado, é levá-lo aos portos Chibatão e Superterminais ${ }^{5}$. Cabe ressaltar que ambos operadores portuários possuem suas próprias ETCs, respectivamente ATR Logística e Supertrans, acirrando a competição com as demais ETCs (Tomiasi, Azevedo, Hebron e Transportes Rodrigo ${ }^{6}$. Além disso, o armador marítimo é o responsável pela negociação com o embarcador da operação completa do contêiner, inclusive da perna rodoviária entre a coleta na fábrica e a entrega no porto (Fotografia 2), e emite o conhecimento de carga.

Os preços médios do mercado por contêiner de 40 pés, revelou Quevedo, estão em R \$ 5 mil o frete marítimo, mais $\mathrm{R} \$ 430$ a coleta/entrega em Manaus, mais $\mathrm{R} \$ 1,2$ mil a coleta/entrega no porto de destino; total de $\mathrm{R} \$$ 6.630. Para fins de comparação, o frete fechado de uma carreta pela intermodalidade rodofluvial fica em torno de R\$16 mil, cerca de 59\% mais caro.

\footnotetext{
4 Entrevista concedida em Uberlândia (MG) em 07.nov.2011.

5 Chibatão e Superterminais também operam no fluxo de navegação de longo curso (importação/ exportação).

6 Para o transporte marítimo de longo curso, a Aliança Navegação e Logística também dispõe de uma ETC para operar o fluxo de contêineres PIM-porto, com frota própria de 10 cavalos mecânicos e 80 carretas.
}

Novos Cadernos NAEA • v. 17 n. $2 \cdot$ p. 95-122 • dez. 2014 
Fotografia 2 - Operação de coleta e/ou entrega no PIM.

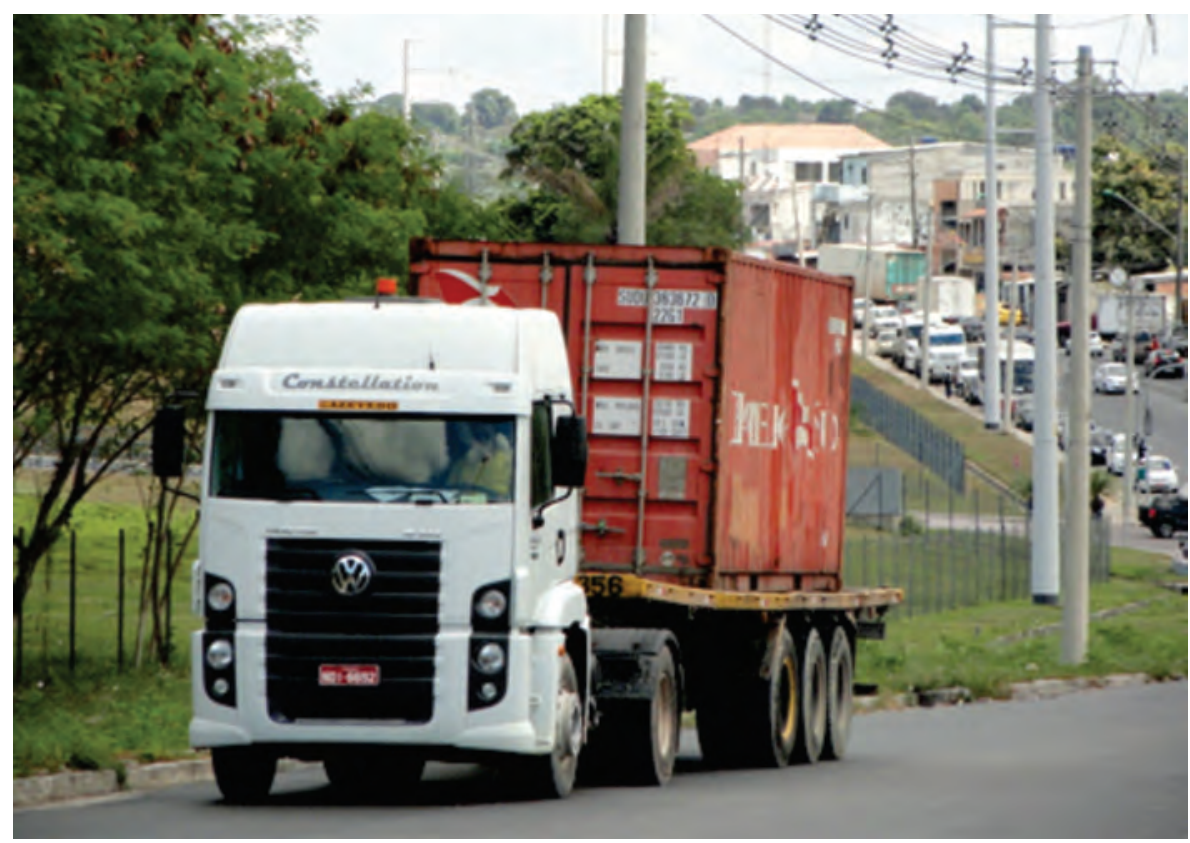

Autor: Daniel M. Huertas (09.jul.2012).

Até mesmo o desvantajoso elevado tempo de trânsito de um navio (15 a 16 dias até Santos ou Sepetiba) se transformou agora em uma vantagem competitiva para os grandes clientes (atacadistas e varejistas), que compram grandes volumes diretamente dos embarcadores, pois passaram a adequar o tempo da viagem com o giro da mercadoria em seus estoques. O equilíbrio entre custo e escala foi possível, considerando-se que um contêiner de 40 pés equivale a $70 \%$ de uma carreta de 15 metros (25 toneladas). "A cada viagem de um dos novos navios da Log-In são retirados das rodovias brasileiras 2.800 caminhões", anuncia o sítio do armador marítimo ${ }^{7}$, demonstrando com exatidão essa questão de escala entre os modais.

Os impactos para o TRC foram imediatos, acarretando em rearranjos operacionais na intermodalidade rodofluvial com o objetivo de reduzir custos. No caso da TNT, segundo Quevedo, houve o aumento da subcontratação na perna rodoviária a partir das regiões Sul, Sudeste e Centro-Oeste, com destino a Belém. A empresa paga o frete fluvial e a taxa diária pelo uso da carreta da ETC subcontratada na balsa e consegue girar mais a sua frota própria - o que significa menos caminhão próprio em Manaus.

In www.loginlogistica.com.br/aniversario_Log-In <Acesso em: 16.out.2012> 
A TNT, inclusive, já deixou de operar com veículos próprios na capital amazonense, fenômeno que está sendo seguido por outras ETCs de grande porte. Na subcontratação, a empresa paga $50 \%$ do valor dos fretes praticados, ou seja, de cada duas viagens ganha uma. A prática gerou um problema fiscal para o transportador que está em discussão, pois como a subcontratação enseja outro serviço, a Secretaria da Fazendo do Pará alega que há um fato gerador novo, com a necessária arrecadação de ICMS. Nos casos anteriores, o conjunto operava em bloco (semirreboque e cavalo da mesma ETC), e dispensava a cobrança.

Raimundo Augusto de Araújo Nonato, secretário do Setcam, anunciou que nos últimos cinco anos o TRC em Manaus caiu de $70 \%$ para 55\% do total de carga movimentada, fato que levou ao enxugamento dos custos, com uso menor de frota própria - durante o trabalho de campo, pudemos constatar ETCs de porte médio como ATL, Click e Mapra com carretas da Bertolini, evidência do aumento da subcontratação na Belém-Brasília - e mais viagens mensais por equipamento, além do ganho por volume e por eixo com o aumento do uso de carretas maiores (de 12 para 15 metros). Essa vantagem, porém, acabou sendo repassada ao tomador do serviço, pois houve queda de $18 \%$ a $22 \%$ no valor dos fretes praticados, segundo o dirigente. "Consequentemente, houve aumento da competição e mortalidade de transportadoras" (informação verbal) ${ }^{8}$.

A divisão do trabalho ainda guarda outras particularidades para os agentes do circuito superior que operam o TRC em Manaus. Para evitar sonegação e comprovar o gozo dos incentivos fiscais, existe a liberação e tributação antecipada da carga por meio eletrônico, um processo de 24 horas que envolve Sefaz/AM e Suframa - e tido pelo setor como um complicador, pois alegam que muitas vezes o processo de liberação da carga leva até 48 horas. No caso do ICMS, um imposto estadual, a alíquota corresponde a 12\%, dos quais $80 \%$ ficam retidos com a Sefaz/AM, e os demais $20 \%$ são recolhidos no ato da geração do conhecimento de carga.

O valor do frete também contempla, além das operações normais de coleta e entrega e o seguro, o frete da balsa e a taxa de movimentação nos portos. Estudo da NTC para o custo da rota São Paulo-Manaus afirma que ainda deve ser levada em consideração a diferença do ciclo operacional dos equipamentos, que resultam em produtividades diferentes. "Enquanto o cavalo faz quase duas viagens e meia por mês e roda $14.500 \mathrm{~km}$, em média, a produção da carreta é praticamente a metade, ou seja, faz 1,2 viagem por mês e roda apenas $7.500 \mathrm{~km}$ mensais" (PEREIRA, 2010, p. 115). A entidade recomenda um preço de frete referencial para carga lotação e valores de acordo com o peso transportado para carga fracionada.

8 Entrevista concedida em Manaus em 09.jul.2012.

Novos Cadernos NAEA • v. 17 n. 2 • p. 95-122 • dez. 2014 
A particularidade que envolve a intermodalidade e a elevada distância de São Paulo (quase 4 mil km) tornam a rota entre Manaus e a capital paulista uma das mais equilibradas do país em termos de equacionamento de fluxos. Quevedo, da TNT, afirmou que de cada 10 carretas cheias subindo a Belém-Brasília, apenas duas descem vazias, em valores idênticos de frete - R\$16 mil por sentido ( $\mathrm{R} \$$ $2,80 / \mathrm{km}$ rodado), incluindo a balsa ( $\mathrm{R} \$ 4,8 \mathrm{mil})$. Nonato, do Setcam, mostra números levemente distintos: R\$10,5 mil no sentido Manaus-São Paulo e R\$ 12 mil no sentido contrário, pois a subida do rio contra a correnteza queima mais óleo diesel.

O equilíbrio também pode ser demonstrado pelos dados de movimentação de semirreboques baú para a navegação interior do país, que ocorre apenas em terminais de uso privado da Bacia Amazônia (Porto Velho, Manaus, Santarém, Belém e Santana/AP). Segundo a Antaq, do total movimentado em 2011 (4.958.702 ton), 2.497.731 ton foram embarcadas, e 2.460.971 ton, desembarcadas. Infelizmente, a agência agrega os dados específicos dos terminais por acondicioamento da carga (granel sólido, granel líquido, carga geral solta e carga geral conteneirizada), fato que compromete uma leitura mais fidedigna dos fluxos.

De todo o fluxo operado no sistema "ro-ro caboclo" com destino a Manaus, cerca de 70\% tem como origem São Paulo (com transbordo intermodal em Belém e Porto Velho, este em menor escala), sobretudo carga composta por insumos industriais (partes e acessórios para motocicletas, tereftalato de polietileno em forma primária e pilhas elétricas de bióxido de manganês etc) e carga fracionada (gêneros alimentícios e vestuário), conforme dados apurados por Carvalho, da Supporte.

De outras partes do Brasil desembarcam sal (Ceará e Rio Grande do Norte), adubo e propileno (Bahia), açúcar (Pernambuco), latas de alumínio (Goiás), arroz e alimentos industrializados da BR Foods (sul do país) e frango congelado (Mato Grosso e Minas Gerais), entre outros. Bertolini, Jatex, SR, Expresso Ocidental, FTD, Gold Brasil, Carinhoso e Sitram são ETCs locais que operam fluxos T1 para outras regiões do país. Cabe ressaltar que o transporte de carga refrigerada exige caminhões com lonas térmicas e semirreboques com evaporadores e divisórias móveis para evitar a troca de calor.

“O Brasil abastece Manaus e Manaus abastece o Brasil”, disse Quevedo, mas ressaltando que o T1/A São Paulo-Manaus-São Paulo é o carro-chefe dessa relação. No frete-retorno, a cabotagem para Manaus está movimentando sal, gêneros alimentícios, cimento, cal, material de construção e trigo. Como anuncia o sítio da Amazon, ETC de São Paulo “especializada em transporte de cargas 
secas destinadas a Manaus - e dessa cidade para todo o Brasil", é o "Brasil Continental integrado de Norte a Sul".

Outro ponto que merece destaque é a não ocorrência de agenciadores de carga no TRC, evidenciando uma cultura rodoviária bastante diferenciada em relação ao restante do país, compreensível diante das particularidades territoriais de Manaus. São as ETCs do circuito superior que estabelecem o contato com motoristas autônomos e elaboram as suas próprias relações de fidelização com agregados. $\mathrm{O}$ fato pode ser verificado até na subcontratação de autônomos com carga originada em São Paulo (fluxo T1/A), que deixam a capital paulista com frete-retorno mais ou menos encaminhado.

Nessa opção a balsa geralmente é paga pelo embarcador (conjunto completo), embora recentemente esteja deixando de ser artifício recorrente, e o Ceasa é o ponto de apoio na cidade amazonense. A prática da extinta carta-frete também não ocorreu por lá, já que o principal fluxo T1/B (Belém-Manaus) é por via fluvial.

Ainda no âmbito do PIM, algumas ETCs mantêm operações dedicadas de tipo just-in-time e milk-run para fornecimento de insumos às fábricas. Como parte expressiva dos insumos chega de avião (sobretudo componentes para celulares, eletroeletrônicos e de informática e circuitos impressos), o terminal de cargas do Aeroporto Eduardo Gomes é um dos mais movimentados do país, com 183.541 toneladas (comércio exterior e carga nacional) em 2011, segundo a Infraero, e os operadores logísticos aeroportuários demandam subcontratação de ETCs, embora a maioria disponha de frota própria.

Além do suprimento e escoamento do PIM, há a distribuição em Manaus (fluxos T2/E), fluxos T1/C para Boa Vista e fluxos T2/D para as poucas cidades do interior amazonense acessíveis por via rodoviária (Presidente Figueiredo, pela BR-174; Rio Preto da Eva, Itacoatiara e Silves, pela AM-010; Iranduba, Manacapuru e Novo Airão pela AM-070; e Careiro da Várzea, Careiro, Manaquiri e Autazes pela BR-369). Para as demais cidades (com exceção de Apuí, no sul do Estado) o abastecimento é feito a partir da capital pelos chamados barcos mistos regionais, que transportam carga e passageiros. A TRA Transportes da Amazônia, fundada em 2006, é uma das ETCs locais especializadas nas rotas que seguem os principais rios do Estado.

Por redespacho, atende Rapidão Cometa, TNT, Braspress e Atlas, que levam a carga de São Paulo para Belém (fluxo T1/A) por via rodoviária e da 
capital paraense para Manaus (fluxo T1/B) pelo sistema "ro-ro caboclo". Após a coleta nas filiais das grandes ETCs supracitadas e da coleta nas fábricas do PIM (Semp Toshiba, Coca-Cola, Hitachi, Fuji Film e CCE, entre outras, e neste caso há emissão de conhecimento de carga), a mercadoria segue para a sua matriz.

Daí até o principal porto de atracação das embarcações regionais, conhecido como Roadway9 (Fotografias 3-5), no centro da cidade, a TRA subcontrata a Transbrito, que coleta a carga no subcontratante e a entrega diretamente no cais ao responsável pelo barco. É a ETC local de pequeno porte que possui todo o conhecimento das rotas do interior no que diz respeito ao tempo de trânsito, custo e agenciamento, pois dispõe do contato com todos os armadores fluviais e com os responsáveis pela coleta da carga nas cidades de destino. O seu frete praticado é um percentual sobre o frete-valor e frete-volume totais.

Fotografia 3 - Embarque de carga para a linha Manaus-Uarini (AM)

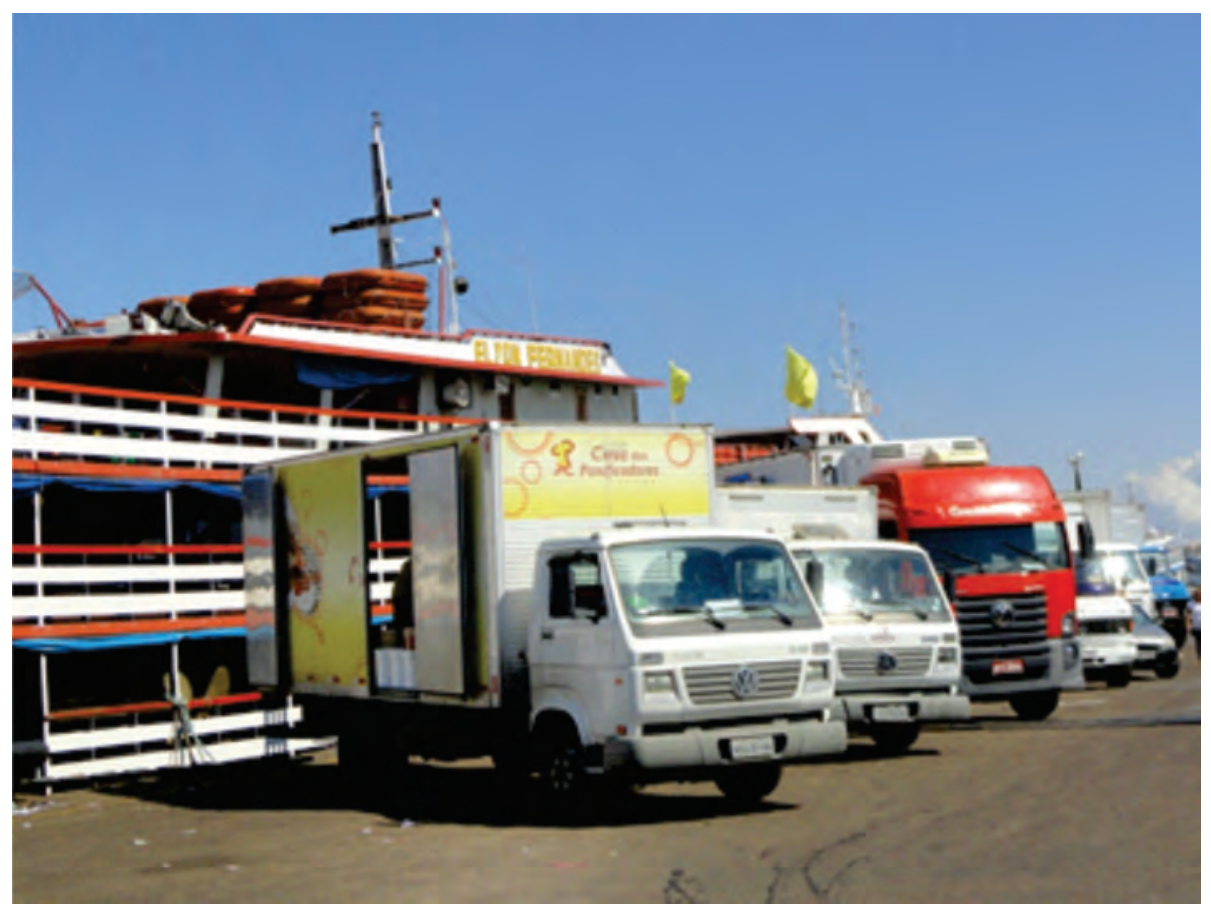

Autor: Daniel M. Huertas (11.jul.2012). O Roadway faz parte do porto organizado de Manaus, que foi retomado pela União após
entraves jurídicos surgidos na concessão para duas empresas privadas. 
Fotografia 4 - Embarque de carga para a linha Manaus-Fonte Boa (AM).

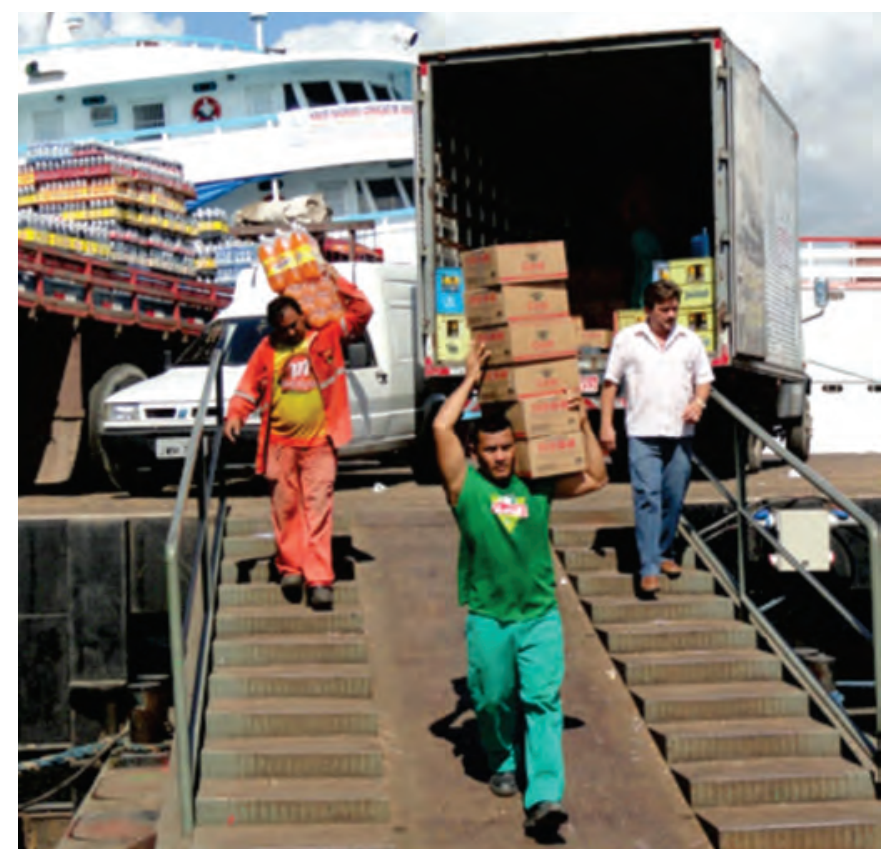

Autor: Daniel M. Huertas (11.jul.2012).

Fotografia 5 - Carregamento de castanha para Óbidos (PA).

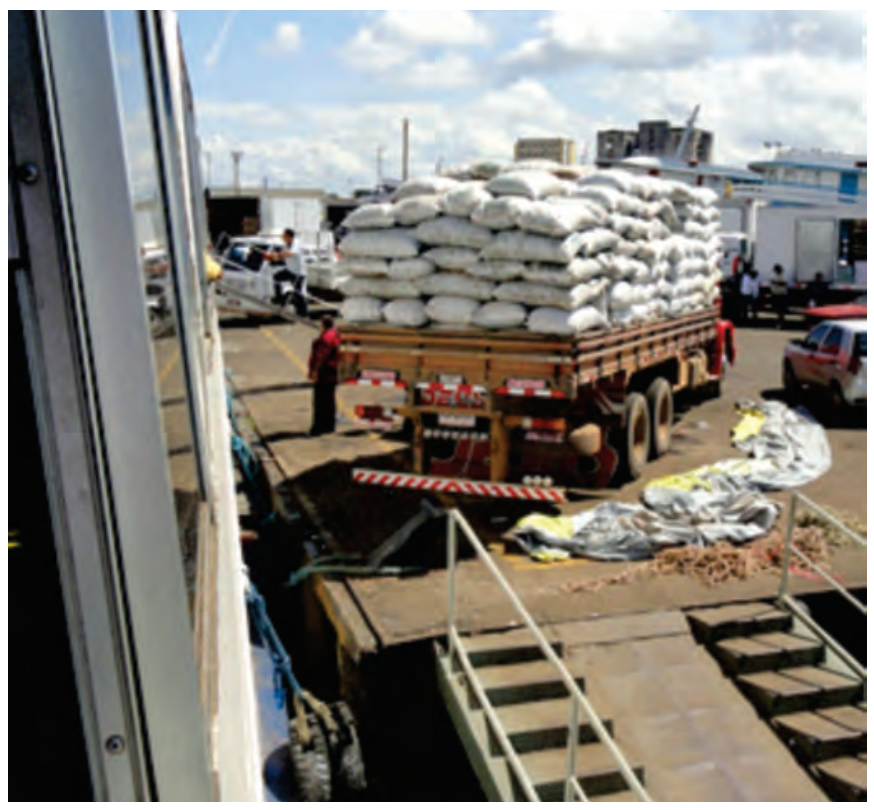

Autor: Daniel M. Huertas (11.jul.2012).

Novos Cadernos NAEA • v. 17 n. 2 • p. 95-122 • dez. 2014 
Na vastidão dos rios do Amazonas, os tempos de entrega são longos: 17 dias para Tabatinga (Solimões), 12 dias para São Gabriel da Cachoeira (Negro), 27 dias para Ipixuna (Juruá), 25 dias para Boca do Acre (Purus) e 12 dias para Humaitá (Madeira), contados a partir da coleta em Manaus. Nessas rotas, a informação praticamente desaparece, pois o contato com o barco só é possível quando o mesmo atraca em alguma cidade.

"Tudo pode acontecer no rio; enquanto um acidente na estrada se resolve em horas, no rio pode demorar dias", explicou Gilvan Huosell Ramos (informação verbal ${ }^{10}$, diretor da TRA, que coloca o diferencial da empresa no conhecimento geográfico e no relacionamento com os parceiros esparramados pelas cidades mais distantes. A empresa conta com seguro da carga no curso fluvial e apesar das dificuldades trabalha com a projeção de cumprimento de prazo de $97 \%$, que tem ficado em torno de $93 \%$.

A presença privilegiada no polo nacional de eletroeletrônicos e duas rodas também levou a TRA a distribuir para toda a Região Norte e para o Mato Grosso, e a composição de seus clientes é um bom indicativo dos nexos territoriais do TRC na Amazônia. Novento por cento da carga é originada em Manaus (produtos do PIM) e 10\% nas regiões Sul e Sudeste, com transbordo em Belém (carga geral para Manaus e Roraima). O movimento total da empresa é assim dividido: 10\% no Amazonas (5\% na capital e 5\% no interior); $13 \%$ em Rondônia; $8 \%$ no Acre; 7\% em Roraima; 5\% no Tocantins; $10 \%$ no Mato Grosso; $40 \%$ no Pará (20\% na Grande Belém) e 7\% no Amapá, segundo Ramos.

De seus 36 veículos, 12 carretas ficam disponíveis apenas para o trecho Manaus-Belém, por onde flui a maior parte de toda a sua circulação. Amazonas, Roraima, Porto Velho e Belém são supridos por frota própria, e o restante envolve um esquema de subcontratações para a realização dos fluxos T1/B e T1/C concentrado na capital paraense (três ETCs subcontratadas para atender todo o Estado do Pará, uma para o Amapá e outra para o Tocantins) e na capital rondoniense (uma ETC subcontratada para atender Rondônia e Acre e outra para o Mato Grosso).

Os projetos de exploração da bauxita em Oriximiná (Mineração Rio do Norte) e Juruti (Alcoa) e as obras das usinas hidrelétricas de Jirau e Santo Antônio, no Rio Madeira, e Belo Monte, no Rio Xingu, demandam grandes máquinas, equipamentos, veículos e insumos transportados por balsas, mas que em algum momento necessitam da presença de um caminhão. A Linave, de Belém, é uma ETC que presta este tipo de serviço intermodal. A Transglobal, de Ananindeua,

10 Entrevista concedida em Manaus em 10.jul.2012. 
também participa ativamente do transporte de cargas especiais e de grande porte, mas não possui operação fluvial.

Em sua porção estritamente rodoviária, o principal fluxo T1/C do Estado é a rota Belém-Marabá pela PA-150, pois é a partir da maior cidade do interior paraense (233.669 habitantes, Censo 2010) que saem os fluxos T1/C e T2/D responsáveis pelo abastecimento de toda a porção sul, incluindo as complicadas rotas pela Transamazônia (BR-230) e Cuiabá-Santarém (BR-163), além das cidades e vilas que compõe a província mineralógica de Carajás. "No inverno a Transamazônica é uma bagaceira e prefiro pegar e passar a entrega para outro", comentou Roberto Mendonça, do Expresso Grão-Pará, que prefere subcontratar autônomos para distribuição em cidades como Pacajá, Anapu, Rurópolis, Presidente Médici, Trairão e Novo Progresso.

Jacareacanga, situada na Transamazônica, próximo da divisa com o Amazonas (e também acessível por Marabá), "se chega a duras penas", conforme comentou Raimundo Esteves (informação verbal) ${ }^{11}$, gerente executivo do Sindicato das Empresas de Logística e Transportes de Cargas no Estado do Pará (Sindicarpa). De acordo com Mendonça, a PA-150 é a rota do Estado com a maior incidência de roubos, principalmente no trecho Moju-Goianésia do Pará. Marabá também é ponto estratégico para distribuição no eixo da PA275 (Carajás, Parauapebas e Canaã dos Carajás), que concentra grande parte da atividade mineradora da Vale no Estado.

O porto organizado de Vila de Conde, em Barcarena (a $119 \mathrm{~km}$ da capital pela alça viária), é centro da produção de alumina e alumínio das jazidas da região de Oriximiná e o principal polo caulinífero ${ }^{12}$ do país. As duas atividades envolvem outros modais (hidroviário e dutoviário) para o fornecimento da matéria-prima (bauxita e caulim), mas demandam TRC para outros insumos. Há grande geração de carga para vergalhões e cabos elétricos de alumínio produzidos pelo Grupo Alubar e no terminal da Santos Brasil, que movimenta contêineres (cerca de 30 mil teus em 2010) e carga de projetos (máquinas e equipamentos) em balsas personalizadas pelos rios Amazonas e Xingu.

Castanhal, quarta maior cidade do Estado com 173.149 habitantes (Censo 2010), está a $70 \mathrm{~km}$ da capital e a $40 \mathrm{~km}$ do entroncamento da BR-316 (que segue para a Região Nordeste) com a BR-010, o trecho paraense da Belém-Brasília. É ponto de concentração de agenciadores de carga e de carreteiros à espera de algum frete-retorno. Para o TRC, é uma espécie de retroárea de Belém.

11 Entrevista concedida em Belém em 16.jul.2012.

12 O caulim é um mineral que tem grande aplicação na produção de papel (preenchimento e revestimento), plásticos, cerâmicas, tintas e borrachas. 
Se o frete-retorno em termos nacionais é um dos sintomas do desenvolvimento desigual e combinado da formação socioespacial brasileira, na Amazônia toma proporções gigantescas por causa das distâncias e do povoamento rarefeito. Para a TRA, o retorno de Roraima e Porto Velho para Manaus é zero; e de Belém, na principal rota, fica 55\% menor. Para o Expresso Grão-Pará, o retorno é 90\% vazio em todas as rotas. Na ligação entre a capital e Marabá há uma particularidade: o intenso fluxo de carretas vazias descendo a PA150 após descarregar carne oriunda dos frigoríficos do sul do Estado minimiza o frete-retorno para o motorista autônomo e serve de ida para a principal filial da empresa.

Já o retorno de Belém para São Paulo, como explicou Esteves, do Sindicarpa, é praticamente carga de Manaus, madeira e castanha. A ligação com o Nordeste é incipiente, de Goiás sobe muito hortifrutigranjeiros e da região Sul, móveis. Solamazon e BR Expresso, de Ananindeua; Bussola, de Marituba; Exa, de Belém; e Transfigueredo, de Castanhal, operam fluxos T1/A-B com outras regiões do país. Amazonlog e Transdourada focam os fluxos rodofluviais T1/C com Amapá e Manaus, respectivamente. Belém e Manaus também albergam terminais de carregamento de combustível e unidades do Sest/Senat.

\section{CONSIDERAÇÕES FINAIS}

O eixo nodal Manaus-Belém pode sofrer transformações substanciais a partir do momento em que estiver concluída a pavimentação da BR-163, mais conhecida por Cuiabá-Santarém. A polêmica estrada apresenta grandes possibilidades econômicas para o escoamento da safra de grãos do Mato Grosso, desafogando o tráfego intenso de carretas rumo aos portos das regiões Sul e Sudeste, e no sentido inverso pode encurtar a "perna fluvial" dos produtos oriundos do PIM com destino ao restante do país, restringindo-a ao trecho Manaus-Santarém.

O asfaltamento da BR-163 é obra do PAC2 - em seu último balanço, divulgado em fevereiro de 2014, $630 \mathrm{~km}$ a partir da divisa MT/PA já estão concluídos, e os demais $382 \mathrm{~km}$ seguem em ritmo "adequado" (298km entre a divisa e Rurópolis/PA, lote 2) e em “atenção” (84km entre Rurópolis e Santarém, lote 1) - e avança gradativamente, apesar das paralisações obrigatórias no período chuvoso (novembro-março). O governo federal tenta a qualquer custo encontrar uma forma de não repetir os erros do passado, quando estradas abertas na Amazônia trouxeram muitos impactos socioambientais. Uma delas é o Plano 
BR-163 Sustentável, mas segundo análises do Grupo de Trabalho Amazônico (GTA), os pontos críticos são a execução do ordenamento fundiário (legalização de terras e realização de assentamentos rurais) e de projetos de uso sustentável, já que muitas ações não saíram do papel.

De concreto sabe-se que as pastagens avançam no norte do Mato Grosso e sul do Pará, e que em 2012 o desmatamento disparou em torno da estrada de acordo com estudos do Instituto do Homem e Meio Ambiente da Amazônia (Imazon). Aceleração das obras e alteração do limite de unidades de conservação adjacentes para viabilizar o complexo de usinas hidrelétricas no Rio Tapajós têm contribuído para estimular as frentes de desmatamento e a especulação fundiária que se cria a partir de uma perspectiva futura.

Como entendemos que a pavimentação da BR-163 é uma obra irreversível e que boa parte dos cenários construídos será alcançada, resta saber quem serão os reais contemplados por esta investida dos atores hegemônicos e de que forma a União se posicionará em relação aos possíveis mandos e desmandos típicos de movimentos de expansão de fronteira. Já discutimos esta questão em estudo anterior (HUERTAS, 2009), e mantemos a visão de que o alargamento das dinâmicas territoriais do Centro-Sul dificilmente poupará esta porção da Amazônia.

Até mesmo Passos (2007), que investigou a problemática mais de perto, admite que hoje já existe um sentimento de pertencimento dos colonos sulistas em relação ao mundo amazônico, apesar dos conflitos entre atores e agendas distintos. O autor afirma que a fronteira se constrói "de dentro para fora", e ainda avança em direção às novas áreas de floresta de transição, como corroboram os estudos supracitados. Não podemos esquecer ainda que as obras da Usina Hidrelétrica de Belo Monte, próximas da área de influência da rodovia e igualmente polêmicas, estão em pleno andamento. Talvez a BR-163 seja uma causa perdida, mas que seja a última cicatriz rodoviária no âmago da floresta.

\section{REFERÊNCIAS BIBLIOGRÁFICAS}

ARROYO, M. Dinâmica territorial, circulação e cidades médias, in SPOSITO, E. S.; SPOSITO, M. E. B.; SOBARZO, O. (orgs.). Cidades médias: produção do espaço urbano e regional. São Paulo: Expressão Popular, 2006, p.71-85.

La división territorial del trabajo: un proceso e una categoría para intepretar el mundo. Anais eletrônicos (cd-rom) da $4^{\text {a }}$ Conferência Internacional de Geografia Crítica, Ciudad de México, 2005, p.1-12. 
BRAGA, V. Logística e uso do território brasileiro: tipologia e topologia de nós logísticos e o projeto da Plataforma Multimodal de Goiás (PLMG). Tese de Doutorado, Universidade de Campinas (Unicamp/IGE), Campinas, 2013.

BRANDÃO, A. C. Território e desenvolvimento: as múltiplas escalas entre o local e o global. $1^{a}$ reimp. Campinas: Unicamp, 2009.

CASTILLO, R. A. Agricultura globalizada e logística nos cerrados brasileiros, in SILVEIRA, Márcio Rogério (org.). Circulação, transportes e logística. São Paulo: Outras Expressões, 2011, p. 331-54.

CLOZIER, R. Géographie de la circulation. Paris: Génin, 1963.

CORRÊA, R. L. Estudos sobre a rede urbana. Rio de Janeiro: Bertrand Brasil, 2006. Interações espaciais, in CASTRO, I. E. de; GOMES, P. C. da C.; CORRÊA, R. L. (orgs.). Explorações geográficas: percursos no fim do século. Rio de Janeiro: Bertrand Brasil, 1997, p. 279-318.

FONSECA, R. O. A circulação através da navegação de cabotagem no Brasil: um sistema de fluxos e fixos aquaviários voltados para a fluidez territorial. Dissertação de Mestrado, Universidade de São Paulo (FFLCH/DG), São Paulo, 2013.

GIÚDICE, F. Como gerir a variação sazonal da demanda, in Anuário NTC\&Logística 2011/2012, São Paulo, 2012, p. 134-37.

HUERTAS, D. M. Território e circulação: transporte rodoviário de carga no Brasil. Tese de Doutorado, Departamento de Geografia, FFLCH/USP, São Paulo, 2013.

Da fachada atlântica à imensidão amazônica: fronteira agrícola e integração territorial. São Paulo: Annablume, 2009.

MARX, K. O capital: crítica da economia política - Livro Segundo: O processo de circulação do capital, volume III. 13.ed. Rio de Janeiro: Civilização Brasileira, 2011 [1893].

PASSOS, M. M. dos. BR-163, de estrada dos colonos a corredor de exportação. Maringá: Massoni, 2007.

NAZARÉ, R. O “roll-on roll-off” na Amazônia. Anais do II Simpósio de Navegação na Amazônia, Belém, 1983.

PEREIRA, J. L. Quanto custa transportar para Manaus, in Anuário NTC\&Logística 2009/2010, São Paulo, 2010, p.114-17.

RAFFESTIN, C. (1980). Por uma geografia do poder. São Paulo: Ática, 1993.

SANTOS, M. (1979). O espaço dividido: os dois circuitos da economia urbana dos países subdesenvolvidos. $2^{\mathrm{a}}$ ed. $1^{\mathrm{a}}$ reimp. São Paulo: Edusp, 2008.

(1993). A urbanização brasileira. 5.ed. São Paulo: Edusp, 2005.

(1996). A natureza do espaço. Técnica e tempo. Razão e emoção. 4.ed. São Paulo: Edusp, 2004.

2003.

(1979). Economia espacial: críticas e alternativas. 2.ed. São Paulo: Edusp, 
Metamorfoses do espaço habitado. São Paulo: Hucitec, 1988.

SAVY, M. Logistique et territoire. Espace géographique, tome 22, n 3, 1993, p.210-18. SILVA JUNIOR, R. F. Geografia de redes e da logística no transporte rodoviário de cargas: fluxos e mobilidade geográfica do capital. Dissertação de Mestrado, Universidade Estadual Paulista (Unesp), Presidente Prudente, 2004.

THOMSON, J. M. Teoría económica del transporte. Madrid: Alianza Editorial, 1976. 